\title{
Effect of Different Locations and Growing Season on Growth and Active Materials of Aloe
}

\author{
Makarem A. Mohamed, Khalid A. Khalid*, Hend E. Wahba, Mohamed E. Ibrahim
}

Research of Medicinal and Aromatic Plants Department, National Research Centre, El-Buhouth St., 12311, Dokki, Cairo, Egypt

Received 09Apr 2017,

Revised 05 Jun 2017,

Accepted09 Jun 2017

Keywords

$\checkmark$ Aloe (Aloe vera),

$\checkmark$ yield,

$\checkmark$ gel,

$\checkmark$ aloin

Khalid A. Khalid ahmed490@gmail.com $+201117727586$

\begin{abstract}
Changes in growth, yield and active materials (gel and aloin) of aloe were investigated with different locations and growing season in Egypt. Aloe plants were cultivated at Ismailia and Giza governorate during two seasons. Plants grown under Ismailia location during $2^{\text {nd }}$ season recoded the highest growth characters (leaf number and leaf weight); (gel); (aloin) with values (11.0, 24.3, and 35.3 plant $^{-1} ; 2.8,5.8$ and $8.9 \mathrm{~kg} \mathrm{plant}^{-1} ; 117.2,241.3$ and 359.8 ton ha ${ }^{-1}$ ); $\left(0.9 \% ; 25.4,52.2\right.$ and 77.6 g plant $^{-1} ; 1054.5,2171.5$ and $\left.3192.4 \mathrm{~kg} \mathrm{ha}^{-1}\right) ;(0.2 \%$; $5.9,12.2$ and $18.1 \mathrm{~g}$ plant ${ }^{-1} ; 246.1,506.7$ and $752.8 \mathrm{~kg} \mathrm{ha}^{-1}$ ) during the $2^{\text {nd }}$ season for offsets, mother and whole plant respectively.
\end{abstract}

\section{Introduction}

Aloe (Aloe vera, FamilyLiliaceae) plant has several biological activities i.e. promotion of wound healing, antifungal, hypoglycemic \& anti-diabetic effects, anti-inflammatory, anticancer, immuno- modulatory and gastro-protective values [1].

Growth, yield and physiological processes of agricultural crops can be affected by environmental factors of different location (LOC) and growing season (GS). In the cases of medicinal plants, LOC and GS cause significant changes in growth and some metabolites products such as active constituents, it means that either of LOC and GS can inhibit or promote growth and development of medicinal plants $[2,3]$. The responses to the LOC and GS are various related to the kind plants [4]. Growth characters, yield and chemical constituents of alfalfa,EryngiumcaucasicumTratuv.andPlectranthusamboinicus (Lour.) were affected with variations of LOC or GS factors [4-6]. The oil content of spearmint (Menthaspicata) grown in Siwa reached 3.0\% but increased to $3.9 \%$ when it was grown in Owainat territory, while it decreased to $1.6 \%$ during cultivation in Arish territory [7]. Egyptian LOC (Beni-Suef, Sohag, Qena and Aswan) caused significant variations in fresh mass, dry mass and oil composition of spearmint (Menthaspicata), Beni-Suef recorded the highest values of fresh and dry mass, the greatest values of oil yield were obtained from the plants produced under Sohage and Aswan LOCs, Aswan, Qena and Sohage recorded the highest values of carovn [8]. Fruit yield and oil composition of Indian fennel were affected by various LOCs in south of Egypt i.e. El-Minia, Assuit, Sohag and Qena. El-Minia and Assuit recorded the heaviest yield of fruits but the highest yields of anethol were recorded under El-Minia LOC [2]. LOC caused significant changes in Xylopiaaethiopica oil [9]. The lowest value of the total main constituents of lemon verbena (LippiacitriodoraL.) was found with August harvest under Upper Egypt LOC while the highest resulted from Nile Delta [10]. The effects of LOC of Toshka and Baloza which located at south and north of Egypt on the growth characters and chemical composition of sweet basil (Ocimumbasilicum L.) were investigated by Abozeed [11]; who found that the highest fresh and dry weight of herb and oil yield were recorded under LOC of Baloza while the greatest values of NPK content were recorded under LOC of Toshka but major constituents of oil were changed under both LOCs. This investigation aimed to study the effect of different LOCs and GS on yield, gel and aloin contents of aloe.

\section{2. Experimental details}

\subsection{Experimental sites}

The experiments were carried out at tow experimental farms located in Ismailia (100 km from Cairo) and Giza (25 km from Cairo) regions, Egypt during the years of 2013:2014 and 2014:2015 to investigate the effects of 
different locations on the growth, yield and chemical composition of A. vera. The soil analyses used in this study were presented in Table 1. Offsets of A. vera were kindly provided by the Department of Medicinal and Aromatic Plants, Ministry of Agriculture, Giza, Egypt. The offsets were transplanted into the open field (one offset per hill) in the first week of April 2013. The experimental area (plot) was $6 \mathrm{~m}^{2}(2 \mathrm{~m} \times 3 \mathrm{~m}$, each plot includes 3 ridges); the distance between hills was $40 \mathrm{~cm}$ and $60 \mathrm{~cm}$ apart between ridges. All agronomic cultural practices operations other than experimental treatments were performed according to the recommendations of the Ministry of Agriculture, Egypt.

Table 1. Mechanical and chemical properties of soil

\begin{tabular}{|l|l|l|}
\hline \multirow{2}{*}{ Items } & \multicolumn{2}{|c|}{ Values } \\
\cline { 2 - 3 } & Ismailia & Giza \\
\hline Texture & Sand & Clay loam \\
\hline $\mathrm{pH}$ & 8.6 & 8.2 \\
\hline $\mathrm{EC}\left(\mathrm{dSm}^{-1}\right)$ & 1.2 & 2.8 \\
\hline $\mathrm{CaCO}_{3}(\%)$ & 8.4 & 3.3 \\
\hline $\mathrm{P}_{2} \mathrm{O}_{5}\left(\mathrm{mg} \mathrm{g}^{-1}\right)$ & 2.1 & 37.9 \\
\hline $\mathrm{N}\left(\mathrm{m} \mathrm{g} \mathrm{g}^{-1}\right)$ & 255 & 478.1 \\
\hline $\mathrm{K}\left(\mathrm{mg} \mathrm{g}^{-1}\right)$ & 3.1 & 35.2 \\
\hline Available $\mathrm{Mn}\left(\mathrm{mg} \mathrm{g}^{-1}\right)$ & 5.1 & 13.6 \\
\hline Available Cu (mg g $)$ & 0.5 & 1.7 \\
\hline Available $\mathrm{Zn}\left(\mathrm{mg} \mathrm{g}^{-1}\right)$ & 0.9 & 2.8 \\
\hline Available Fe $\left(\mathrm{mg} \mathrm{g}^{-1}\right)$ & 1.7 & 3.4 \\
\hline
\end{tabular}

\subsection{Vegetative growth measurements}

Number of leaves $\left(\right.$ plant $\left.^{-1}\right)$ and weight of leaves $\left(\mathrm{kg} \mathrm{plant}^{-1} \&\right.$ ton ha $\left.^{-1}\right)$ were recorded in offsets and mother plant then were calculated for the whole plant during the 2013:2014 and subsequent 2014:2015 years.

\subsection{Chemical constituent measurements (active materials)}

Aloe gel was prepared from Aloe leaf according to McAnalley [12].Phenolic compounds (as crude aloin) were determined according to Mahran [13].Gel and crude aloin (percentage, $\mathrm{g} \mathrm{plant}^{-1} \& \mathrm{~kg} \mathrm{ha}^{-1}$ ) were recorded in offsets and mother plant and were calculated for whole plant during the first and second year.

\subsection{Statistical analysis}

For the purpose of analyses, two factors (LOC and years) were considered: two LOC and two years. For each treatment there were 3 replicates. The experimental design followed a complete random block design according to Snedecor [14]. The averages of data were statistically analyzed using 2-way analysis of variance (ANOVA). Significant values determined according to $\mathrm{P}$ values $(\mathrm{P}<0.05=$ significant, $\mathrm{P}<0.01=$ moderate significant and $\mathrm{P}<0.001=$ highly significant). The applications of that technique were according to the STAT-ITCF program [15].

\section{Results and discussion}

\subsection{Effect of LOC, GS and their interactions on growth characters}

Data presented in Table 2 and Fig. 1 shows the effect of different LOCs and GS on growth characters [leaf number plant ${ }^{-1}$ and leaf weight $\left(\mathrm{kg} \mathrm{plant}^{-1} \&\right.$ ton ha $\left.{ }^{-1}\right)$ ] of aloe plants. LOC caused a highly significant effect $(\mathrm{P}<$ $0.001)$ on growth characters of offsets, mother and whole plant. The highest values of growth characters were recorded with the plants cultivated in Ismailia LOC during $2^{\text {nd }}$ seasons. Greatest values were 11.0, 24.3, and 35.3 plant $^{-1} ; 2.8,5.8$ and $8.9 \mathrm{~kg} \mathrm{plant}^{-1} ; 117.2,241.3$ and 359.8 ton ha ${ }^{-1}$ for offsets, mother and whole plant respectively. The variation in growth characters under two locations may be due to the effect of the variation of soil, air temperature, humidity, radiation, precipitation, winds, altitude, duration of exposure to sun, and wind patterns which led to the different effects on growth characters [11]. Theses results are in accordance with those obtained by Abd El- Wahab [2,8] who found that significant changes in the growth characters of spearmint and Indian fennel under different location of Upper Egypt. LOC and GS caused significant variations in growth characters of some medicinal plants [4-6]. 
Table 2. Effect of LOC, GS and their interactions on growth characters

\begin{tabular}{|c|c|c|c|c|c|c|c|c|c|c|}
\hline \multirow{3}{*}{\multicolumn{2}{|c|}{ Treatments }} & \multicolumn{9}{|c|}{ Growth characters } \\
\hline & & \multirow{2}{*}{\multicolumn{3}{|c|}{ Leaf number $\left(\right.$ plant $^{-1}$ ) }} & \multicolumn{6}{|c|}{ Leaf weight } \\
\hline & & & & & \multicolumn{3}{|c|}{$\mathrm{Kg}\left(\right.$ plant $\left.^{-1}\right)$} & \multicolumn{3}{|c|}{ ton $\mathrm{ha}^{-1}$} \\
\hline Locations & Seasons & Offsets & Mother & Whole & Offsets & Mother & Whole & Offsets & Mother & Whole \\
\hline \multirow{2}{*}{ Giza } & $1^{\mathrm{st}}$ & 4.9 & 17.0 & 21.9 & 0.9 & 2.1 & 2.9 & 35.3 & 85.2 & 120.5 \\
\hline & $2^{\text {nd }}$ & 5.6 & 20.3 & 25.9 & 1.1 & 3.6 & 4.7 & 43.4 & 149.9 & 193.3 \\
\hline \multicolumn{2}{|c|}{ Overall Giza } & 5.3 & 18.7 & 23.9 & 1.0 & 2.9 & 3.8 & 39.4 & 117.5 & 156.9 \\
\hline \multirow{2}{*}{ Ismailia } & $1^{\mathrm{st}}$ & 6.3 & 16.7 & 23.0 & 0.9 & 2.7 & 3.6 & 37.4 & 113.0 & 150.5 \\
\hline & $2^{\text {nd }}$ & 11.0 & 24.3 & 35.3 & 2.8 & 5.8 & 8.9 & 117.2 & 241.3 & 359.8 \\
\hline \multicolumn{2}{|c|}{ Overall Ismailia } & 8.7 & 20.5 & 29.2 & 1.9 & 4.3 & 6.3 & 77.3 & 177.2 & 255.2 \\
\hline \multirow{2}{*}{$\begin{array}{l}\text { Overall } \\
\text { Seasons }\end{array}$} & $1^{\mathrm{st}}$ & 5.6 & 16.9 & 22.5 & 0.9 & 2.4 & 3.3 & 36.4 & 99.1 & 135.5 \\
\hline & $2^{\text {nd }}$ & 8.3 & 22.3 & 30.6 & 2.0 & 4.7 & 6.8 & 80.3 & 195.6 & 276.6 \\
\hline \multicolumn{11}{|c|}{ F value } \\
\hline \multicolumn{2}{|c|}{ Locations } & $75.7^{\mathrm{hs}}$ & $8.1^{\mathrm{hs}}$ & $50.0^{\mathrm{hs}}$ & $336.1^{\text {hs }}$ & $462.3^{\text {hs }}$ & $750.9^{\text {hs }}$ & $467.9^{\text {hs }}$ & $445.6^{\mathrm{hs}}$ & $803.9^{\text {hs }}$ \\
\hline \multicolumn{2}{|c|}{ Seasons } & $45.6^{\mathrm{hs}}$ & $72.6^{\mathrm{hs}}$ & $120.5^{\text {hs }}$ & $469.4^{\text {hs }}$ & $1225.0^{\mathrm{hs}}$ & $1500.9^{\mathrm{hs}}$ & $624.3^{\text {hs }}$ & $1166.2^{\mathrm{hs}}$ & $1655.7^{\mathrm{hs}}$ \\
\hline \multicolumn{2}{|c|}{ Locations X Seasons } & $26.4^{\text {hs }}$ & $11.3^{\mathrm{hs}}$ & $31.7^{\mathrm{hs}}$ & $289.0^{\text {hs }}$ & $132.3^{\text {hs }}$ & $336.1^{\mathrm{hs}}$ & $415.3^{\mathrm{hs}}$ & $126.6^{\mathrm{hs}}$ & $388.4^{\mathrm{hs}}$ \\
\hline
\end{tabular}

\subsection{Effect of LOC, GS and their interactions on gel and crude aloin contents}

Highly significant $(\mathrm{P}<0.001)$ changes in gel contents $\left(\%, \mathrm{~g}\right.$ plant ${ }^{-1}$ and $\left.\mathrm{kg} \mathrm{ha}^{-1}\right)$ were found under different LOCs during both seasons (Table 3 and Fig. 1). Plants cultivated in Ismailia LOC produced the highest values of gel contents at $2^{\text {nd }}$ season. The highest values were $0.9 \% ; 25.4,52.2$ and $77.6 \mathrm{~g}_{\text {plant }}{ }^{-1} ; 1054.5,2171.5$ and $3192.4 \mathrm{~kg} \mathrm{ha}^{-1}$ of offsets, mother and whole plant respectively.

The values of crude aloin were investigated with Ismailia\& Giza locations and Gs factors (Table 4). Changes in GS resulted in highly significant changes of aloin content $\left(\%, \mathrm{~g} \mathrm{plant}^{-1}\right.$ and kg ha $\left.{ }^{-1}\right)$. LOC and GS x LOC caused an insignificant change in aloin percentage while resulted in a highly significant change in aloin content such as $\mathrm{g}$ plant ${ }^{-1}$ or $\mathrm{kg} \mathrm{ha}^{-1}$. Plants cultivated with Ismailia produced the highest contents of aloin with values of $0.2 \%$; 5.9, 12.2 and $18.1 \mathrm{~g} \mathrm{plant}^{-1} ; 246.1,506.7$ and $752.8 \mathrm{~kg} \mathrm{ha}^{-1}$ during the $2^{\text {nd }}$ season for offsets, mother and whole plant respectively.

Table 3. Effect of LOC, GS and their interactions on gel contents

\begin{tabular}{|c|c|c|c|c|c|c|c|c|c|c|}
\hline \multirow{2}{*}{\multicolumn{2}{|c|}{ Treatments }} & \multicolumn{9}{|c|}{ Gel contents } \\
\hline & & \multicolumn{3}{|c|}{$\%$} & \multicolumn{3}{|c|}{.g plant ${ }^{-1}$} & \multicolumn{3}{|c|}{$\mathrm{kg} \mathrm{ha}^{-1}$} \\
\hline Locations & Seasons & Offsets & Mother & Whole & Offsets & Mother & Whole & Offsets & Mother & Whole \\
\hline \multirow{2}{*}{ Giza } & $1^{\text {st }}$ & 0.3 & 0.3 & 0.3 & 2.43 & 5.7 & 8.5 & 100.9 & 236.3 & 337.2 \\
\hline & $2^{\text {nd }}$ & 0.3 & 0.3 & 0.3 & 2.90 & 10.1 & 13.0 & 121.3 & 422.0 & 543.2 \\
\hline \multicolumn{2}{|c|}{ Overall Giza } & 0.3 & 0.3 & 0.3 & 0.3 & 7.9 & 10.8 & 111.1 & 329.2 & 440.2 \\
\hline \multirow{2}{*}{ Ismailia } & $1^{\mathrm{st}}$ & 0.3 & 0.3 & 0.3 & 2.7 & 8.1 & 10.8 & 112.3 & 339.0 & 451.4 \\
\hline & $2^{\text {nd }}$ & 0.9 & 0.9 & 0.9 & 25.4 & 52.2 & 77.6 & 1054.5 & 2171.5 & 3192.4 \\
\hline \multicolumn{2}{|c|}{ Overall Ismailia } & 0.6 & 0.6 & 0.6 & 0.6 & 30.2 & 44.2 & 583.4 & 2171.5 & 1821.9 \\
\hline \multirow{2}{*}{$\begin{array}{l}\text { Overall } \\
\text { Seasons }\end{array}$} & $1^{\mathrm{st}}$ & 0.3 & 0.3 & 0.3 & 2.7 & 6.9 & 9.7 & 106.6 & 287.7 & 394.3 \\
\hline & $2^{\text {nd }}$ & 0.6 & 0.6 & 0.6 & 25.4 & 52.2 & 77.6 & 1054.5 & 2171.5 & 3192.4 \\
\hline \multicolumn{11}{|c|}{ F value } \\
\hline \multicolumn{2}{|c|}{ Locations } & $10206.0^{\text {hs }}$ & $10206.0^{\mathrm{hs}}$ & $10206.0^{\mathrm{hs}}$ & $1582.8^{\text {hs }}$ & $5092.1^{\text {hs }}$ & $3964.6^{\mathrm{hs}}$ & $1590.6^{\text {hs }}$ & $5199.7^{\mathrm{hs}}$ & $1322.6^{\mathrm{hs}}$ \\
\hline \multicolumn{2}{|c|}{ Seasons } & $9154.6^{\mathrm{hs}}$ & $9154.6^{\mathrm{hs}}$ & $9154.6^{\mathrm{hs}}$ & $1639.1^{\mathrm{hs}}$ & $6048.6^{\text {hs }}$ & $4503.5^{\text {hs }}$ & $1650.4^{\text {hs }}$ & $6173.5^{\text {hs }}$ & $1504.2^{\mathrm{hs}}$ \\
\hline \multicolumn{2}{|c|}{ Locations X Seasons } & $9257.1^{\text {hs }}$ & $9257.1^{\mathrm{hs}}$ & $9257.1^{\mathrm{hs}}$ & $1509.3^{\text {hs }}$ & $4039.2^{\mathrm{hs}}$ & $3423.2^{\mathrm{hs}}$ & $1514.6^{\text {hs }}$ & $4110.4^{\text {hs }}$ & $1113.2^{\mathrm{hs}}$ \\
\hline
\end{tabular}

The variations in yield, gel and aloin composition under LOC and GS could be due to its effect of various LOC and GS on enzymes activity and metabolism improvements of aloe plants [16]. Special processing of plant metabolism affected by cultivated the crops under different LOC and GS factors such as temperature, humidity, radiation, precipitation, winds, altitude, duration of exposure to sun, and wind patterns have a direct influence, especially in species that have histological structures for the storage chemical constituents [17]. 


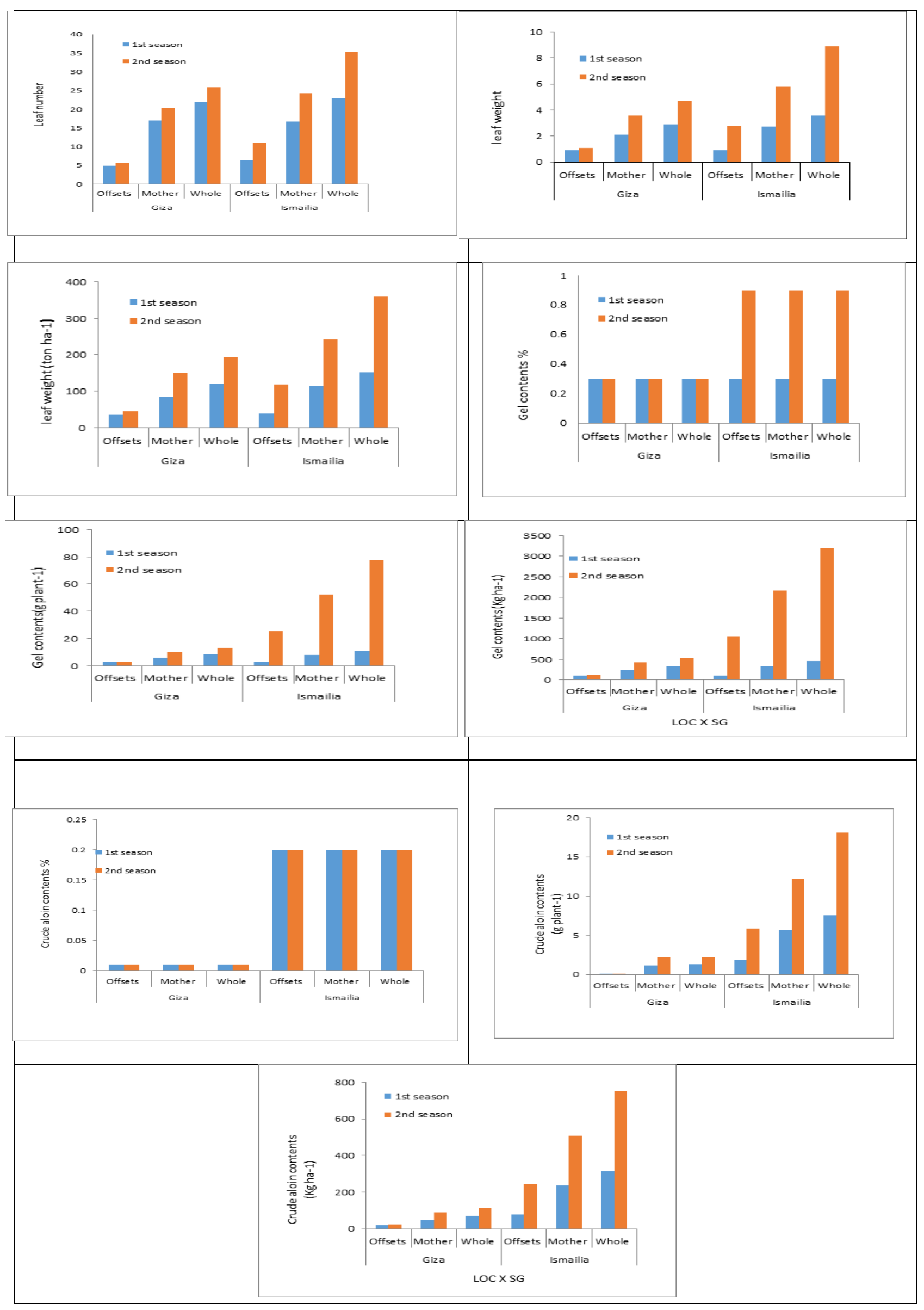

Fig. 1. Effect of LOC x GS on growth and chemical contents of aloe 
Obtained results are in accordance with those obtained by previous investigators. The greatest values of spearmint oil resulted from plants cultivated with Owainat region and the lowest were obtained from the plants grown under Arish area [7]. LOC and GS caused significant variation in chemical constituents of some medicinal plants [4-6]. El-Minia governorate is better than other governorates of south of Egypt to produce anithole of Indian fennel [2]. Lemon verbena constituents were found higher in Upper Egypt than North [10]. Oil contents significantly changed under different location of Egypt [11].

Table 4. Effect of LOC, GS and their interactions on aloin contents

\begin{tabular}{|c|c|c|c|c|c|c|c|c|c|c|}
\hline \multirow{2}{*}{\multicolumn{2}{|c|}{ Treatments }} & \multicolumn{9}{|c|}{ Crude aloin contents } \\
\hline & & \multicolumn{3}{|c|}{$\%$} & \multicolumn{3}{|c|}{ g plant $^{-1}$} & \multicolumn{3}{|c|}{$\mathrm{kg} \mathrm{ha}^{-1}$} \\
\hline Locations & Seasons & Offsets & Mother & Whole & Offsets & Mother & Whole & Offsets & Mother & Whole \\
\hline \multirow{2}{*}{ Giza } & $1^{\text {st }}$ & .tr & .tr & .tr & 0.1 & 1.2 & 1.3 & 21.2 & 49.6 & 70.8 \\
\hline & $2^{\text {nd }}$ & tr & tr & tr & 0.1 & 2.2 & 2.2 & 24.2 & 89.0 & 113.2 \\
\hline \multicolumn{2}{|c|}{ Overall Giza } & tr & tr & tr & 0.1 & 1.7 & 1.8 & 22.7 & 69.3 & 92.0 \\
\hline \multirow{2}{*}{ Ismailia } & $1^{\mathrm{st}}$ & 0.2 & 0.2 & 0.2 & 1.9 & 5.7 & 7.6 & 78.6 & 237.3 & 316.2 \\
\hline & $2^{\text {nd }}$ & 0.2 & 0.2 & 0.2 & 5.9 & 12.2 & 18.1 & 246.1 & 506.7 & 752.8 \\
\hline \multicolumn{2}{|c|}{ Overall Ismailia } & 0.2 & 0.2 & 0.2 & 3.8 & 9.0 & 12.9 & 162.4 & 372.0 & 534.5 \\
\hline \multirow{2}{*}{$\begin{array}{l}\text { Overall } \\
\text { Seasons }\end{array}$} & $1^{\mathrm{st}}$ & 0.1 & 0.1 & 0.1 & 1.0 & 3.5 & 4.5 & 49.9 & 143.5 & 193.5 \\
\hline & $2^{\text {nd }}$ & 0.1 & 0.1 & 0.1 & 3.0 & 7.2 & 10.2 & 135.2 & 297.9 & 433.0 \\
\hline \multicolumn{11}{|c|}{ F value } \\
\hline \multicolumn{2}{|c|}{ Locations } & $2472.2^{\mathrm{hs}}$ & $2472.2^{\mathrm{hs}}$ & $2472.2^{\mathrm{hs}}$ & $3483.1^{\mathrm{hs}}$ & $5025.5^{\mathrm{hs}}$ & $5994.0^{\mathrm{hs}}$ & $730.6^{\mathrm{hs}}$ & $8705.9^{\mathrm{hs}}$ & $5176.3^{\text {hs }}$ \\
\hline \multicolumn{2}{|c|}{ Seasons } & $0.0^{\mathrm{ns}}$ & $0.0^{\mathrm{ns}}$ & $0.0^{\mathrm{ns}}$ & $955.7^{\mathrm{hs}}$ & $1308.7^{\mathrm{hs}}$ & $1599.2^{\mathrm{hs}}$ & $902.2^{\mathrm{hs}}$ & $1315.1^{\mathrm{hs}}$ & $1522.7^{\mathrm{hs}}$ \\
\hline \multicolumn{2}{|c|}{ Locations X Seasons } & $0.0^{\mathrm{ns}}$ & $0.0^{\mathrm{ns}}$ & $0.0^{\mathrm{ns}}$ & $949.4^{\mathrm{hs}}$ & $716.5^{\mathrm{hs}}$ & $1105.4^{\mathrm{hs}}$ & $345.3^{\mathrm{hs}}$ & $1289.3^{\mathrm{hs}}$ & $1032.2^{\mathrm{hs}}$ \\
\hline
\end{tabular}

Studies conducted by Lima et al. [18] showed that the amount of special metabolites produced during the development of the plant can be affected by different locations which are very different in radiation (high or low), temperature (high or low), precipitation (high, low, and total dry matter), winds, altitude, soil, and time of harvest, among other factors. Temperature, relative humidity, the total duration of exposure to sun, and wind patterns have a direct influence, especially in species that have histological structures for the storage of chemical constituents on the plant organs [19].

Climatic variability affects crop development and yield via linear and non-linear response to weather variables and exceeding of well-defined crop thresholds, particularly, temperature. In the processes of plant growth, leaf litter fall to soil ground then under different temperature condition various processes under going inside as well as outside the soil surface and many processes and reactions directly affected by rising temperature, decomposition, weathering and mass flow diffusion etc. may hasten in the soil under optimum soil moisture condition. At low temperatures, the reaction processes become slower, temperature can indirectly affect plant morphology, growth, roots turn over etc., if it is both beyond and under the optimum level for the plants. In addition, soil moisture, salinity, availability of nutrient and minerals together with other processes will play an important role in plant growth and development [20]. Soil moisture and salinity affected growth and chemical constituents of basil, Pelargonium, lemon balm, black cumin and oregano plants [21 -25]. Nutrients can promoted growth and chemical contents of anise, coriander and sweet fennel [26].

\section{Conclusion}

It may conclude that Aloe plants grown under Ismailia location had higher values of growth, yield, gel and aloin contents than those grown with Giza location. LOC caused a highly significant effect $(\mathrm{P}<0.001)$ on growth characters of offsets, mother and whole plant. The highest values of growth characters were recorded with the plants cultivated in Ismailia. Highly significant $(\mathrm{P}<0.001)$ changes in gel contents $\left(\%\right.$, g plant ${ }^{-1}$ and kg ha $\left.{ }^{-1}\right)$ were found under different LOCs. Changes in GS resulted in highly significant changes of aloin content. LOC and GS x LOC caused an insignificant change in aloin percentage while resulted in a highly significant change in aloin content 


\section{References}

1. Hamman J.H., Mole. 13 (2008) 1599.

2. AbdEl-Wahab M. A., Mehasen H. R.A., J. App. Sci. Res. 5 (2009) 677.

3. Khalid A. K., El-Gohary A. E., Int. Food Res. J. 21(2014) 1859.

4. Devlin R., New York, NY: D. Van, Nostrand Company. (1975).

5. Julier B., Huyghe C., Agron. 17 (1997) 481.

6. Hashimobadi D., Kaviani B., Amer. Eur.J. Agric. Env. Sci. 8 (2010) 212.

7. Edris A. E., Shalaby A. S., Fadel H. M., Abdel-Wahab M. A., Eur. Food Res. Tech. 218 (2003) 74.

8. AbdEl-Wahab M. A., Res. J. Agric. Bio. Sci. 5(2009) 250.

9. Elhassan I.A., Ayoub S.M.H., Amer. J.Res. Commun. 2 (2014) 251.

10. Ibrahim M.E., Mohamed M.A., khalid A K., J. Ess.Oil Bear.Plant.17 (2014) 288

11. Abozeed A. E., El-Shafey R.M., Osman A.H., J. Agric.Chem. Biotechn. Mansoura Univ. 6 (2015) 1.

12. McAnalley B.H., United States Patent 4 (1990) 214.

13. Mahran G. H., Darwish S., El-Keiy M., Proc. Pharma. Soc.Egypt 40 (1958) 149.

14. Snedecor G. W., Cochran W. G., Iowa State Univ. Press. Ames. Iowa, USA. (1990).

15. Foucart T., Masson, ITCF, Paris (1982).

16. Burbott A.J., Loomis D., Plant Phys. 44 (1969) 173.

17. Valmorbida J., Boaro C.F.S., Marques M.O.M., Ferri A.F., A Rev. Bras. Plant. Med. 8 (2006) 56.

18. Lima H. R. P., Kaplan M. A. C., Cruz A. V. M., Floresta e Ambiente 2 (2003) 71.

19. Valmorbida J. Boaro, C.F.S., Marques, M.O.M., Ferri A.F., Rev. Bras. Pla. Med. 8 (2006) 56.

20. PorterJ.R.,Smenenov M.A., Phil.Trans. R.Soc.B 360 (2005) 2021.

21. Khalid KA., Int. Agrophys. 20 (2006) 289.

22. Khalid A.K., da Silva J. T., Cai W.,Scientia Hort., 125 (2010) 159.

23. Khalid A.K., Ahmed M.A. J. Mat. Envir. Sci., 8 ( 2017) 7.

24. Ahmed A. M. A., Talaat I. M., Khalid A. K., Int. J. Bot., 13 (2017) 43.

25. Khalid A.K., Cai W., Acta Eco. Sin., 31 (2011) 112.

26. Khalid A.K., J. Soil Sci. Plant Nut.,12 (2012) 617.

(2017) ; http://www.jmaterenvironsci.com 